\title{
Corrigendum:The mineral question: how energy and technology will determine the future of mining
}

\author{
Ugo Bardi * \\ Dipartimento di Scienze della Terra, Università di Firenze, Firenze, Italy \\ ${ }^{*}$ Correspondence: ugo.bardi@unifi.it \\ Edited by: \\ Bin Chen, Beijing Normal University, China \\ Reviewed by: \\ Bin Chen, Beijing Normal University, China \\ Wenjie Liao, Institut National de la Recherche Agronomique, France
}

Keywords: mineral industry, mineral depletion, peak oil, energy production, energy policy, energy transition

\section{A corrigendum on}

The mineral question: how energy and technology will determine the future of mining

by Bardi U (2013). Front. Energy Res. 1:9. doi:10.3389/fenrg.2013.00009

A concept has been mistakenly attributed to the authors of the book while it should have been attributed to the authors of an article in it. The reference of the following sentence should therefore be Valero et al., 2010 rather than Stanek et al., 2010.

'The exergy of mineral deposits can be referenced to a "zero level" state that corresponds to the average concentration of the elements of the ore in the crust.'
The References change also accordingly:

Valero, A. L., Valero, A., and Martínez, A. (2010). Inventory of the exergy resources on earth including its mineral capital. Energy 35, 989-995. doi:10.1016/j.energy. 2009.06.036

\section{Instead of}

Stanek, W., Valero, A., Valero, A., and Martínez, A. (2010). Inventory of the exergy resources on earth including its mineral capital. Energy 35, 989-995. doi: 10.1016/j.energy.2009.06.036

Conflict of Interest Statement: The author declares that the research was conducted in the absence of any commercial or financial relationships that could be construed as a potential conflict of interest.

Received: 07 April 2014; paper pending published: 11 April 2014; accepted: 11 April 2014; published online: 01 May 2014.

Citation: Bardi U (2014) Corrigendum: The mineral question: how energy and technology will determine the future of mining. Front. Energy Res. 2:15. doi: 10.3389/fenrg.2014.00015

This article was submitted to Energy Systems and Policy, a section of the journal Frontiers in Energy Research. Copyright (C) 2014 Bardi. This is an open-access article distributed under the terms of the Creative Commons Attribution License (CC BY). The use, distribution or reproduction in other forums is permitted, provided the original author(s) or licensor are credited and that the original publication in this journal is cited, in accordance with accepted academic practice. No use, distribution or reproduction is permitted which does not comply with these terms. 